\title{
Gold-Silver Kyplatap Ore Knot within the Okhotsk-Chukotka Volcanogenic Belt, Eastern Russia

\author{
T. PAVlOVA $^{1,2^{*}}$, A. PILITSYN $^{1 * *}$
}

${ }^{1}$ Institute of Mineralogy, Geochemistry and Crystal

Chemistry of Rare Elements, Moscow, Veresaeva 15, 121357

Russia (*allafia@yandex.ru, **allexpil@yandex.ru)

${ }^{2}$ IGEM RAS, Moscow, Staromonetny 35, 119017 Russia

Kyplatap is a gold ore knot in the west Chukotka, arranged to the MZ Okhotsk-Chukotka volcanogenic belt (OCVB). Within the volcanic complexes of the OCVB the deposits of silver-gold adular-quartz type were formed, displaying clear correlation with Cretaceous granitoid intrusions [1]. A summary geochemical mapping within the OCVB allowed to distinguish geochemical zones associated with ore-forming processes of a global rank by the $\mathrm{Au}^{*} \mathrm{Ag}$ *As index. Thus, the Kyplatap area, with a contrasting index anomaly, was selected for detailed study. Large deposits Kupol, Sopka Rudnaya, Dvoynoe are the closest analogues of Kyplatap [2].

After the recent field works within the area 2000 samples of the bedrocks were analysed with the portable X-ray, Auspectrochemical, semi-quantitative spectrochemical and fire assay methods. Polished sections were researched by optic and scanning electron microscopy. Ore occurs in highly altered felsic rocks (metasomatic zoning: mudstones - quartzites propylites) and is characterized by the structural position in the frame of the annular volcanic-tectonic depression, with the deep granite batholith under it (geophisycal data), the presence of electrum, acanthite, Ag sulfosalts. Within the mineralized zones an average content of $\mathrm{Au} 3.2 \mathrm{ppm}$ (up to $15 \mathrm{ppm}$ ) and Ag - 850 ppm (up to 2974 ppm). Predicted resources of $\mathrm{P}_{2}$ category are calculated: Au - 20 t, Ag - 5000 t.

Thus, the Kytlatap knot confirms the link of the ore mineralization with the areas of OCVB Cretaceous intrusive granitoid magmatism, reflected in negative gravitational anomalies [1], together with the $\mathrm{Au}^{*} \mathrm{Ag}^{*} \mathrm{As}$ index.

[1] Volkov et al. (2017), Prospects of gold mining development in the Chukotka AD, The Arctic: ecology and economy. no 4 (28), pp. 83 - 97. [2] Strujkov et al. (2005), The Metallogeny of Gold and Silver in the OCVB, Scientific World. 